\title{
A DECISION SUPPORT SYSTEM FOR COST DETERMINATION IN GRAIN STORAGE FACILITY OPERATIONS ${ }^{1}$
}

\author{
DOMINGOS S. M. VALENTE ${ }^{2}$, DANIEL M. DE QUEIROZ ${ }^{3}$, PAULO C. CORRÊA ${ }^{4}$, \\ LUIS C. DA SILVA ${ }^{5}$, SÔNIA M. L. R. DO VALE
}

\begin{abstract}
Many research works have being carried out on analyzing grain storage facility costs; however a few of them had taken into account the analysis of factors associated to all preprocessing and storage steps. The objective of this work was to develop a decision support system for determining the grain storage facility costs and utilization fees in grain storage facilities. The data of a CONAB storage facility located in Ponta Grossa - PR, Brazil, was used as input of the system developed to analyze its specific characteristics, such as amount of product received and stored throughout the year, hourly capacity of drying, cleaning, and receiving, and dispatch. By applying the decision support system, it was observed that the reception and expedition costs were exponentially reduced as the turnover rate of the storage increased. The cleaning and drying costs increased linearly with grain initial moisture. The storage cost increased exponentially as the occupancy rate of the storage facility decreased.
\end{abstract}

KEYWORDS: costs, modeling, software.

\section{UM SISTEMA DE APOIO À DECISÃO PARA DETERMINAÇÃO DE TARIFAS EM UNIDADES ARMAZENADORAS DE GRÃOS}

RESUMO: Vários trabalhos de análise de custos em unidades armazenadoras de produtos agrícolas foram conduzidos; no entanto, poucos abordam as análises dos efeitos dos fatores associados a cada uma das etapas do pré-processamento e armazenagem. Desse modo, o objetivo deste trabalho foi desenvolver um sistema de apoio à decisão para determinação de custos e tarifas em unidades armazenadoras de produtos agrícolas. Uma unidade da CONAB, localizada em Ponta Grossa - PR, foi usada para geração de resultados conforme suas características específicas, tais como quantidade de produto recebido e estocado ao longo do ano, capacidade horária de secagem, limpeza, recepção e expedição. Ao empregar o sistema de apoio à decisão, foi constatado que os custos de recepção e expedição diminuem exponencialmente com o aumento do índice de rotatividade da unidade armazenadora; que os custos de limpeza e secagem foram aproximadamente lineares e crescentes com o aumento do teor de água inicial do produto, e que o custo de armazenagem apresentou comportamento exponencial crescente com a redução do índice de ocupação da unidade armazenadora.

PALAVRAS-CHAVE: custos, modelagem, programa computacional.

\section{INTRODUCTION}

Storage units are structures designed and managed to perform unit operations such as reception, cleaning, drying, storage and dispatch. In service units, such as cooperatives and general stores, transactions rates are billed per ton of product. Thus, it is assumed that these rates should be established to cover the costs of infrastructure, labor, energy, taxes, insurance, and a return on the capital invested.

\footnotetext{
${ }^{1}$ Extraído da dissertação de mestrado do primeiro autor.

${ }^{2}$ Eng ${ }^{\circ}$ Agrícola, DSc., Prof. Adjunto, DEA-UFV, Viçosa - MG, valente@ufv.br.

${ }^{3}$ Eng $^{\mathrm{o}}$ Agrícola, Ph.D., Prof. Associado, DEA-UFV, Viçosa - MG, queiroz@ufv.br.

${ }^{4}$ Eng $^{\mathrm{o}}$ Agrônomo, DSc., Prof. Associado, DEA-UFV, Viçosa - MG, copace@ufv.br.

${ }^{5}$ Eng $^{\mathrm{o}}$ Agrícola, DSc., Prof. Adjunto, DER-UFES, Alegre - ES, silvalc@cca.ufes.br.

${ }^{6}$ Eng $^{\mathrm{a}}$ Agrônoma, DSc., Prof. Associado, DER-UFV, Viçosa - MG, smleite@ufv.br.

Recebido pelo Conselho Editorial em: 5-11-2010

Aprovado pelo Conselho Editorial em: 12-5-2011
} 
According to FIELD et al. (2007), the determination of costs is relevant to the engineering analysis and management of the process, being a basis for decision-making. There are several methods of cost estimation, and among them is the economic engineering method, which is based on the relationship between the inputs used and the products produced.

SILVA et al. (2006) developed an estimation work of the operating costs in storage units. The fixed costs considered were infrastructure insurance, depreciation, repair and maintenance, and the salaries of officials related to the company. The variable costs considered were electricity consumption, temporary labor, insurance of the stored products, and wood for heating the drying air. The authors concluded that the cost factors of highest impact were wages, operational costs of storage, electricity and firewood.

The drying operation has been the subject of cost analysis in several studies, due to the large number of variables that influence the processing power and energy efficiency. REINATO et al. (2002) evaluated the energy consumption and cost of drying coffee cherries using firewood and liquefied petroleum gas (LPG). The authors found that the drying cost using LPG was 2.25 to 4-fold higher than with using wood. SANTOS et al. (2006) found that the cost of drying coffee cherries was 3.20-fold greater for charcoal when compared to firewood. COSTA et al. (2010) analyzed the feasibility of using coffee rotary dryers for drying corn using LPG as fuel. They concluded that the cost of drying in rotary dryers outweighed the costs of commercial dryers.

JASPER et al. (2006), in an analysis of the cost of storage and drying corn in a dryer silo, obtained values ranging from $\mathrm{R} \$ 23.67$ to $\mathrm{R} \$ 48.83$ per ton, considering a storage period of twelve fortnights. The highest value was observed in the dryer silo with lowest static capacity, which made the venture economically unfeasible for the study.

TILLEY et al. (2007) developed an empirical economic model to minimize costs by using thermal and chemical treatment to the level of risk associated with insect attacks in stored grains. FLINN (2007), following the same strand of research, developed a decision support system to provide information for insect management of stored wheat. For this, the authors used a model to predict the future risk based on insect density, temperature and moisture content of the stored wheat.

Due to the large number of variables that influence the costs of unit operations carried out in storage units. This work aims at developing a decision support system with access to the Internet to determine the costs and rates of unit operations regarding reception, cleaning, drying, storage and dispatch of grains in storage facilities.

\section{MATERIAL AND METHODS}

This work was carried out in a region with subtropical climate with an average temperature of $13{ }^{\circ} \mathrm{C}$ in winter and $21.4{ }^{\circ} \mathrm{C}$ in summer in the municipality of Ponta Grossa - PR, Brazil. We used data collected in the storage unit of the National Supply Company - CONAB - to feed the system. To implement the model, the PHP programming language (ACHOUR et al., 2007), version 4.3.10, and the MySQL database (AXMARK, 2007) version 4.1.9, which are public domain tools, were used. The system was designed to be accessed over the Internet and was called STARWEB.

Costs were calculated for the unit operations of reception, cleaning, drying, storage and dispatch, determined in Brazilian reais $(\mathrm{R} \$)$ per ton for each unit operation. For this, we considered depreciation, repair and maintenance, interest on average capital invested, insurance, taxes and housing, labor, electricity, and fuel for heating the drying air, conform methodologies proposed by VALENTE et al. (2008) and MERCANTE et al. (2010).

Figure 1 illustrates the simplified flowchart of the algorithm developed in which the calculations were first made with all items of common costs to all unit operations, facilitating the reuse of code within a program structure. Then we calculated the cost per ton of product, considering the specific details of each unit operation. 

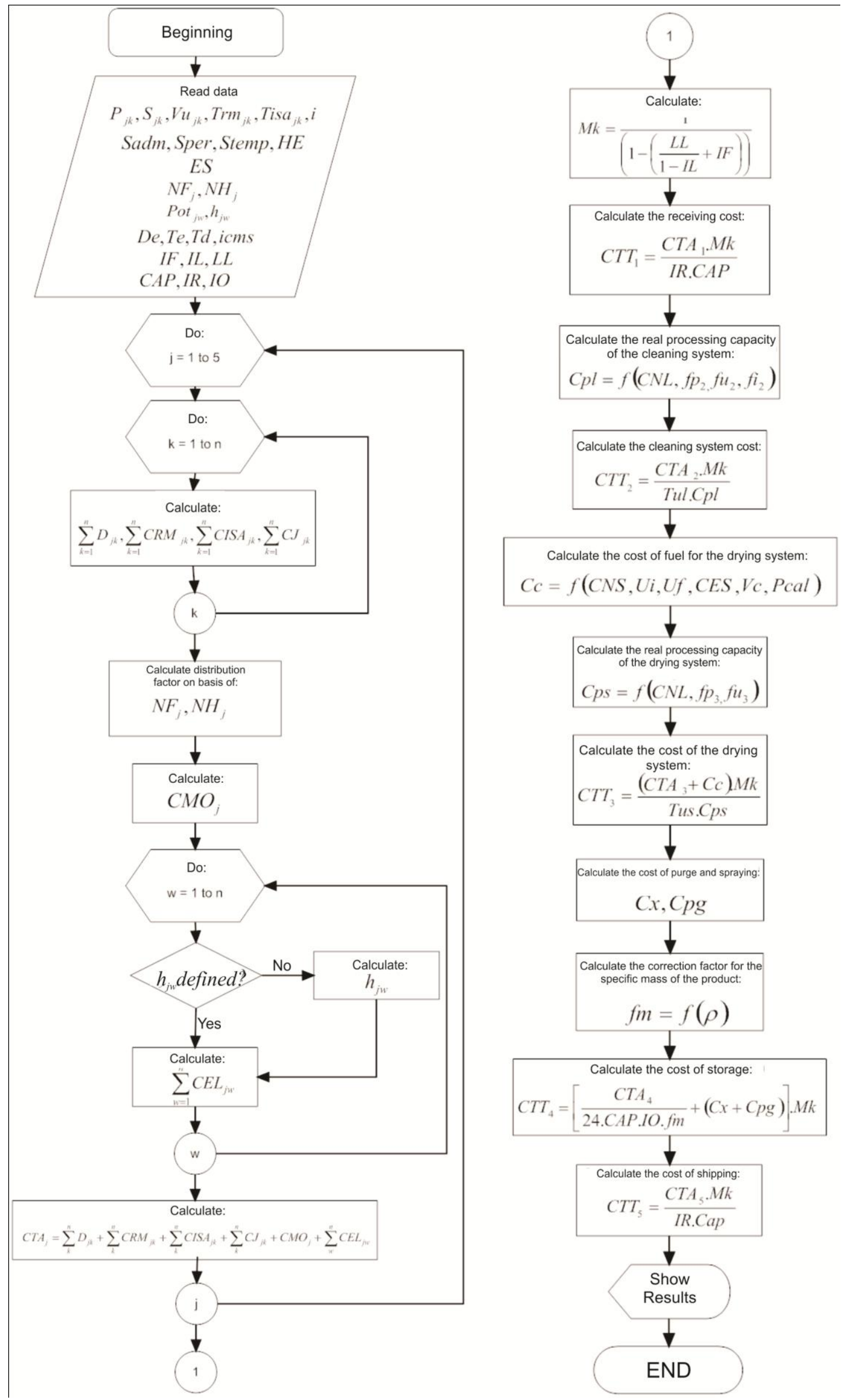

FIGURE 1. Simplified flowchart of the algorithm developed for calculation of costs and fees in storage facilities. 
To prepare this flowchart, it was used the following variables:

$J \quad-j^{\text {th }}$ unit operation, $\mathrm{j}=1$ (reception), $\mathrm{j}=2$ (cleaning system), $\mathrm{j}=3$ (drying system), $\mathrm{j}=4$ (storage), $\mathrm{j}=5$ (dispatch);

$K \quad-\quad k^{\text {th }}$ equipment or structure;

$W \quad-w^{\text {th }}$ installed power;

$P_{j k} \quad-\quad$ new value of the $k^{\text {th }}$ equipment or structure for the $j^{\text {th }}$ unit operation, $\mathrm{R} \$$;

$S_{j k} \quad-\quad$ residual value of the $k^{\text {th }}$ equipment or structure for the $j^{\text {th }}$ unit operation, in relation to the new value, decimal;

$V u_{j k} \quad-\quad$ life of the $k^{\text {th }}$ equipment or structure for the $j^{\text {th }}$ unit operation, years;

$i \quad$ - annual interest rate, decimal;

$\operatorname{Trm}_{j k} \quad-\quad$ rate of repair and annual maintenance of the $k^{\text {th }}$ equipment or structure for the $j^{\text {th }}$ unit operation, decimal;

Tisa $a_{j k} \quad-\quad$ rate of tax, insurance and accommodation of the $k^{\text {th }}$ equipment or structure for the $j^{\text {th }}$ unit operation, decimal;

Sadm - sum of the salaries of central administration, prorated for unit, R\$.month ${ }^{-1}$;

Sper - sum of the salaries of permanent labor, R\$.month ${ }^{-1}$;

ES - social charges, \%;

Stemp - sum of the salaries of temporary labor, $\mathrm{R} \$ . \mathrm{month}^{-1}$;

$H E \quad$ - cost of overtime, R\$.month ${ }^{-1}$;

$N F_{j} \quad-\quad$ number of employees used in the $j^{\text {th }}$ unit operation, dimensionless;

$\mathrm{NH}_{j} \quad$ - number of working hours of the $j^{\text {th }}$ unit operation, hours.year ${ }^{-1}$;

Pot ${ }_{j w} \quad-w^{\text {th }}$ installed power for the $j^{\text {th }}$ unit operation, $\mathrm{kW}$;

$h_{j w} \quad-\quad$ number of hours the $w^{\text {th }}$ installed power for the $j^{\text {th }}$ unit operation, hours.month ${ }^{-1}$;

Te $\quad-\quad$ cost of electricity, R\$.kW.h ${ }^{-1}$;

De - average of used or hired demand, kW.month ${ }^{-1}$;

Td - fee of electricity demand, $\mathrm{R} \$ . \mathrm{kW}^{-1}$;

icms - rate of tax on movement of goods and services (ICMS) for power, decimal;

Cap - static storage capacity, $\mathrm{t}$;

IR - turnover rate of the storehouse, dimensionless;

IO - index of storehouse occupation, decimal;

$D_{j k} \quad-\quad$ depreciation of the $k^{\text {th }}$ equipment or structure for the $j^{\text {th }}$ unit operation, R $\$ . y e a r^{-1}$;

$C J_{j k} \quad-\quad$ cost of interest on capital invested in the $k^{\text {th }}$ equipment or structure for the $j^{\text {th }}$ unit operation, R\$.year ${ }^{-1}$;

$C R M_{j k} \quad$ - cost of repair and maintenance of the $k^{\text {th }}$ equipment or structure for the $j^{\text {th }}$ unit operation, R\$.year ${ }^{-1}$;

$C I S A_{j k} \quad-\quad$ cost of taxes, insurance and accommodation of the $k^{\text {th }}$ equipment or structure for the $j^{\text {th }}$ unit operation, $\mathrm{R} \$$.year ${ }^{-1}$;

$C M O_{j} \quad-\quad$ cost of labor of the $j^{\text {th }}$ unit operation, $\mathrm{R} \$$. year $^{-1}$;

$C E L_{j} \quad-\quad$ cost of electricity of the $j^{\text {th }}$ unit operation, $\mathrm{R} \$ . y e a r^{-1}$;

$C T A_{j} \quad$ - cost of the $j^{\text {th }}$ unit operation, considering the cost items common to all operations, $\mathrm{R} \$$ year $^{-1}$;

IF $\quad$ - tax on gross sales, decimal;

$L L \quad$ - annual net profit, decimal;

IL $\quad$ - tax on net profit, decimal;

$M k \quad$ - coefficient for net profit, net profit tax and tax on gross sales, decimal;

$C T T_{1} \quad-\quad$ cost of reception, $\mathrm{R} \$ . \mathrm{t}^{-1}$; 
$C T T_{2} \quad-\quad$ cost of the cleaning system, $\mathrm{R} \$ . \mathrm{t}^{-1}$;

$C p l \quad-\quad$ effective processing capacity of the cleaning system, $\mathrm{R} \$ . \mathrm{t}^{-1}$;

CNL - nominal capacity of the cleaning system, t.h ${ }^{-1}$;

$\mathrm{fp}_{2} \quad$ - correction factor for product type of the cleaning system, decimal;

$\mathrm{fu}_{2} \quad$ - correction factor for water content of the product of the cleaning system, decimal;

$f_{2} \quad$ - correction factor for impurity content of the product of the cleaning system, decimal;

Tul - average time of the cleaning system, h.year ${ }^{-1}$;

Cc - fuel cost for drying, $\mathrm{R} \$ \cdot \mathrm{h}^{-1}$;

CNS - nominal capacity of the drying system, $\mathrm{t}^{-1}{ }^{-1}$;

$U i \quad$ - initial water content of the product, \%w.b.;

Uf - water content of the final product after drying, \%w.b.;

CES - technical coefficient of specific energy consumption of the dryer (kJ per kg water), $\mathrm{kJ} \mathrm{kg}^{-1}$;

$V c \quad$ - fuel price, $\mathrm{R} \$ \cdot \mathrm{kg}^{-1}$;

Pcal - calorific fuel value, $\mathrm{kJ}_{\mathrm{kg}}{ }^{-1}$;

Cps - effective processing capacity of the drying system, $\mathrm{t}^{-1}{ }^{-1}$;

$\mathrm{fp}_{3} \quad$ correction factor for the type of product drying system, decimal;

$\mathrm{fu}_{3} \quad$ - correction factor to the water content of initial and final drying of the product, decimal;

Tus - average time of the drying system, h.year ${ }^{-1}$;

$C T T_{3} \quad$ - drying cost, $\mathrm{R} \$ . \mathrm{t}^{-1}$;

$C x \quad-\quad$ purge cost, $\mathrm{R} \$ \mathrm{t}^{-1}$. fortnight ${ }^{-1}$;

Cpg - cost of spraying of bulk products, $\mathrm{R} \$ \cdot \mathrm{t}^{-1}$. fortnight ${ }^{-1}$;

$f m \quad-$ correction factor of density, dimensionless;

$\rho \quad$ - product density, kg.m- ${ }^{3}$;

$\mathrm{CTT}_{4} \quad$ - fortnight cost of storage, $\mathrm{R} \$ . \mathrm{t}^{-1}$;

$C T T_{5} \quad-\quad$ dispatch cost, $\mathrm{R} \$ \cdot \mathrm{t}^{-1}$.

It was obtained the costs of receiving, cleaning, drying, storage and dispatch of rice, corn, soybean and wheat with initial moisture content of $18 \%$ w.b. and impurity content of $3 \%$. We considered drying of the product with natural gas to final water content of $13 \%$ w.b. The average storage of the product at the storehouse was set for an occupancy rate of 0.80 . The amount of product received on the unit was defined by a turnover rate of 1.00 .

It was performed sensitivity analysis by changing the values presented in Table 1 .

TABLE 1. Variables used in the sensitivity analysis for the storage unit.

\begin{tabular}{ll}
\hline Variable & Range studied \\
\hline Turnover rate of the storage unit & 0.60 to 3.0 - dimensionless \\
Occupancy index of storage & 0.10 to 1.0 - dimensionless \\
Initial water content of the drying product & 15 to $28 \%$ w.b. \\
Final water content of the drying product & $13 \%$ w.b. \\
Type of fuel used for drying & Wood, LPG, Natural Gas \\
Initial impurity content of the product & 3 to $6 \%$ \\
Water content of the product in the cleaning system & 15 to $28 \%$ w.b. \\
\hline
\end{tabular}




\section{RESULTS AND DISCUSSION}

Table 2 shows the specific costs of rice, corn, soybeans and wheat, assuming initial and final water content of $18 \%$ w.b. and $13 \%$ w.b., respectively, an initial impurity content of $3 \%$, a turnover rate equal to 1.00 , an occupancy rate equal to 0.80 and the use of natural gas as drying fuel. Considering a storage period of twelve fortnights, we obtained, in descending order of total cost per ton, the values of $\mathrm{R} \$ 41.52, \mathrm{R} \$ 27.69, \mathrm{R} \$ 25.47$ and $\mathrm{R} \$ 22.92$ for rice, corn, wheat and soybean, respectively.

For the same conditions and period, CONAB (2011) practiced a total fee per ton of rice of $\mathrm{R} \$ 42.15$, and $\mathrm{R} \$ 37.32$ for all other products. The price of rice practiced by CONAB was close to the value determined in this study; however the same was not true for other products. This was due to the lower occupancy rate of CONAB units, resulting in higher storage costs per fortnight. CONAB considers corn, wheat and soybean with single fees. However, with the results obtained one can see that there are differences of up to $20.81 \%$ in the final costs per ton between these products.

TABLE 2. Costs of unit operations of the storage unit.

\begin{tabular}{lrrrr}
\hline \multirow{2}{*}{ Unit operation } & \multicolumn{4}{c}{ Product Cost } \\
\cline { 2 - 5 } & \multicolumn{1}{c}{ Rice } & \multicolumn{1}{c}{ Corn } & Soybean & Wheat \\
\hline Reception $\left({\mathrm{R} \$ \mathrm{t}^{-1}}^{-1}\right)$ & 2.28 & 2.28 & 2.28 & 2.28 \\
Drying $\left(\mathrm{R} \$ \mathrm{t}^{-1}\right)$ & 25.89 & 14.76 & 11.07 & 11.07 \\
Cleaning $\left(\mathrm{R} \$ \mathrm{t}^{-1}\right)$ & 1.80 & 1.02 & 1.02 & 1.02 \\
Storage $\left(\mathrm{R} \$ \mathrm{t}^{-1}\right.$ fortnight $\left.^{-1}\right)$ & 0.80 & 0.64 & 0.55 & 0.61 \\
Dispatch $\left(\mathrm{R} \$ \mathrm{t}^{-1}\right)$ & 1.95 & 1.95 & 1.95 & 1.95 \\
\hline
\end{tabular}

It can be seen in Table 2 that the cost of receiving and dispatch did not differ for product type, however, for the cleaning, drying and storage costs there was variation among different products.

For the cost of drying and cleaning, the observed differences were due to lower hourly capacity of rice processing in relation to other products, mainly soybean and wheat, thus contributing to higher costs per ton of processed product. The cost for soybean and wheat was $\mathrm{R} \$$ 0.18 per kilogram of water removed, $\mathrm{R} \$ 0.24$ per $\mathrm{kg}$ of water removed for corn, and $\mathrm{R} \$ 0.42$ per $\mathrm{kg}$ of water removed for rice. It appears that the type of product has an important significance in the final drying cost by directly contributing to the processing capacity of the dryer.

DONZELES et al. (2007), in a work to determine the cost of drying coffee, found a lower cost of $\mathrm{R} \$ 1.15$ per kilogram of water removed, higher than for other products in the present study. This is due to the particularities of coffee drying in relation to the products analyzed in this study. Therefore, this reinforces the importance of product type in the final composition of drying costs.

The highest storage cost was estimated for rice, caused by cost estimations of spraying and purge. Soybean showed the lowest cost, because there was no incidence of pests in this product, with no cost to purge and spraying. By making the composition of the cost of storage and drying of corn, for a period of twelve fortnights, we obtained a cost of $\mathrm{R} \$ 22.44$ per ton, lower than the cost obtained by JASPER et al. (2006) in a dryer silo.

Figure 2 shows the receiving and dispatch costs depending on the turnover rate of the storage unit. 


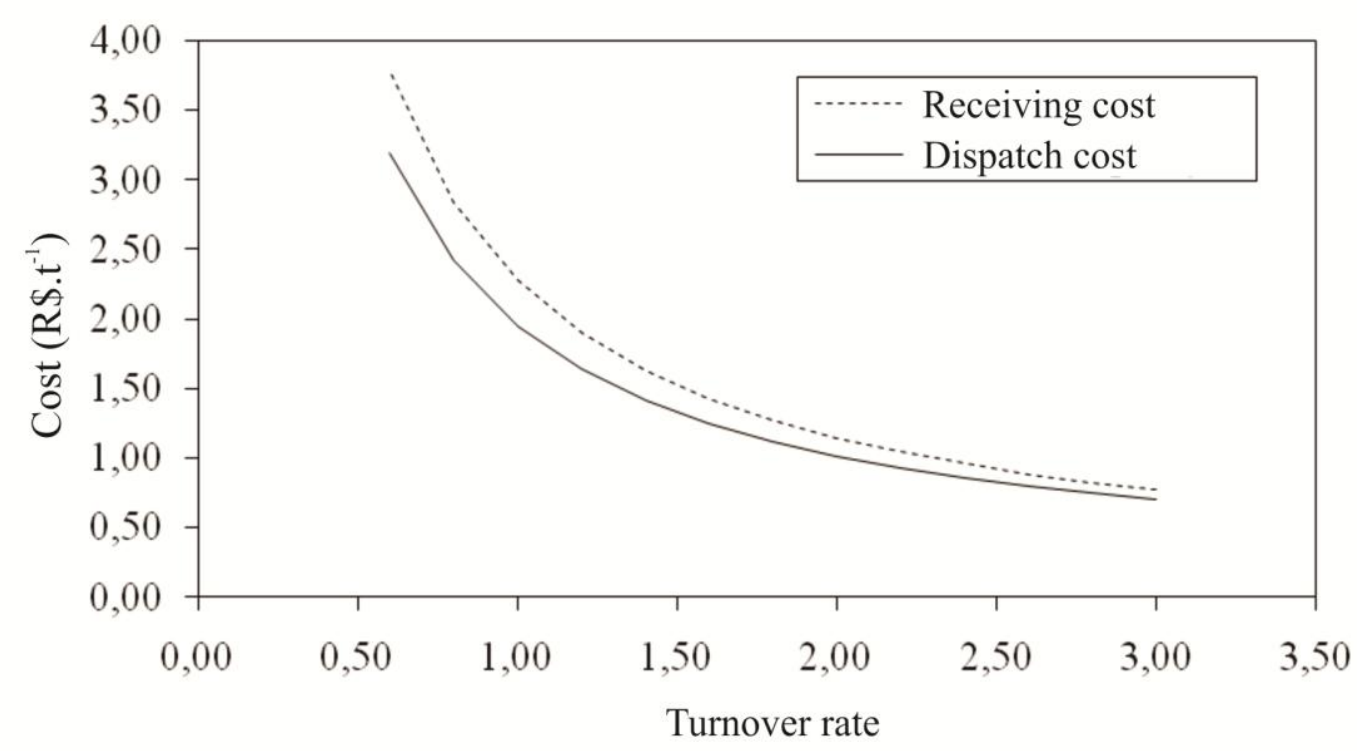

FIGURE 2. Receiving and dispatch costs depending on the turnover rate.

According to Figure 2, it is noticed that the receiving and dispatch costs decrease exponentially with an increasing turnover rate of the storage unit. This is due to a greater dilution of the fixed costs to a larger amount of product processed. The cost of reception was greater than the cost of dispatch across the range of variation in turnover rate. The reception had a higher cost due to higher fixed cost of this operation, since it requires more expensive infrastructure and higher labor cost. Some storage units may have reception labor costs as a function of the quantity of product received, thus turning it in a variable cost. On the other hand, other units may have specific equipment that reduces the need for labor, which can increase the fixed cost. However, this fixed cost can be diluted in a larger quantity of product received, turning the investment more viable.

Figure 3 shows the results of drying cost of corn using different types of fuel sources.

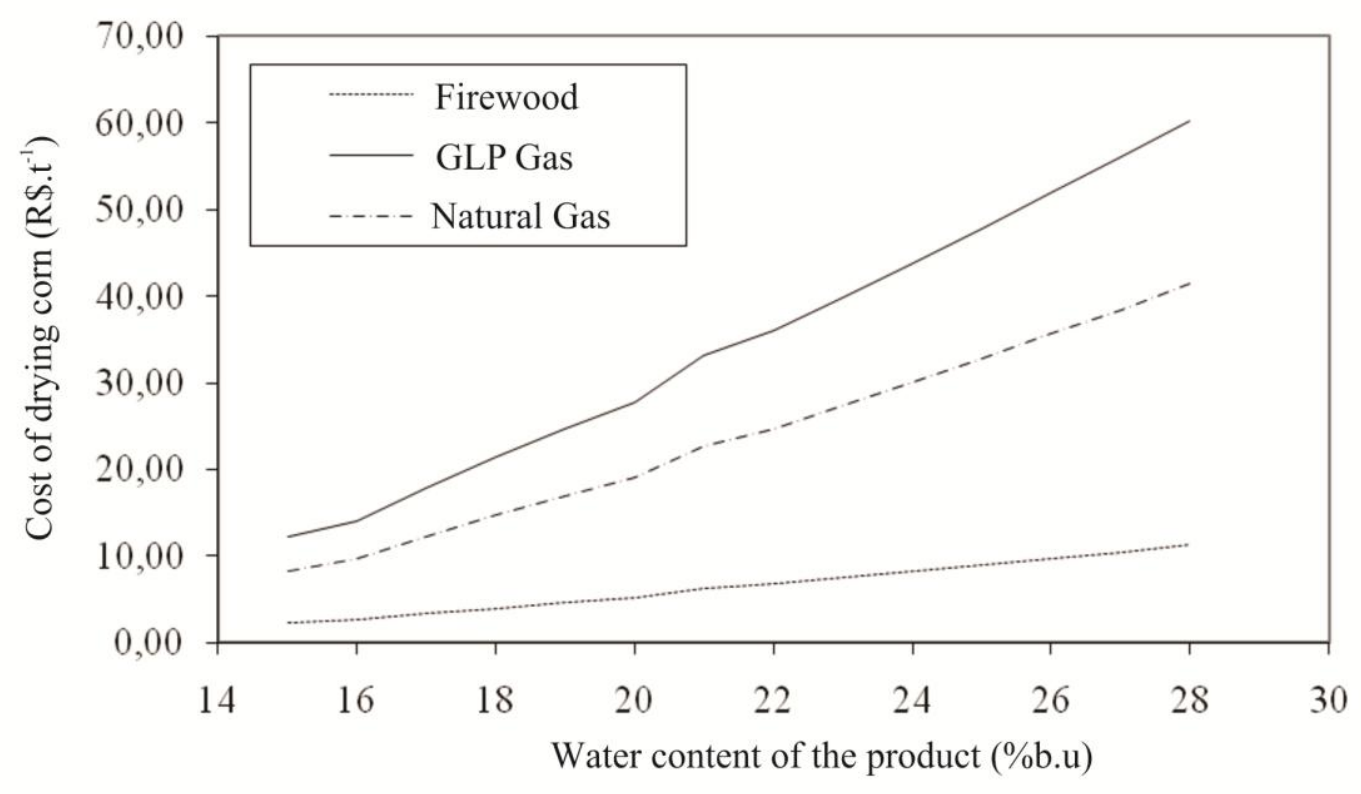

FIGURE 3. Cost of drying corn as a function of initial water content of the product using different fuel sources.

It is observed that wood was the fuel that resulted in the lowest drying costs. Despite showing the lowest calorific value, the wood has also a low acquisition cost, which makes this fuel viable for 
drying agricultural products, a result also observed by other authors (REINATO et al., 2002; SANTOS et al., 2006; AFONSO JÚNIOR et al., 2006; COSTA et al., 2010). The drying cost of corn using LPG with initial and final water content of $18 \%$ w.b. and $13 \%$ w.b., respectively, was R\$ 21.50 per ton. COSTA et al. (2010) using LPG as fuel obtained drying costs of R $\$ 38.50$ per ton of dry corn with initial and final water content of $18 \%$ w.b. and $12.4 \%$ w.b., respectively. The difference between these results can be attributed mainly to a lower hourly capacity of the dryers analyzed by the author. When increasing the hourly dryer capacity, fixed costs are diluted in a larger amount of processing product. Figure 4 presents the results of the cleaning cost of corn as a function of impurity and initial water content of the product.

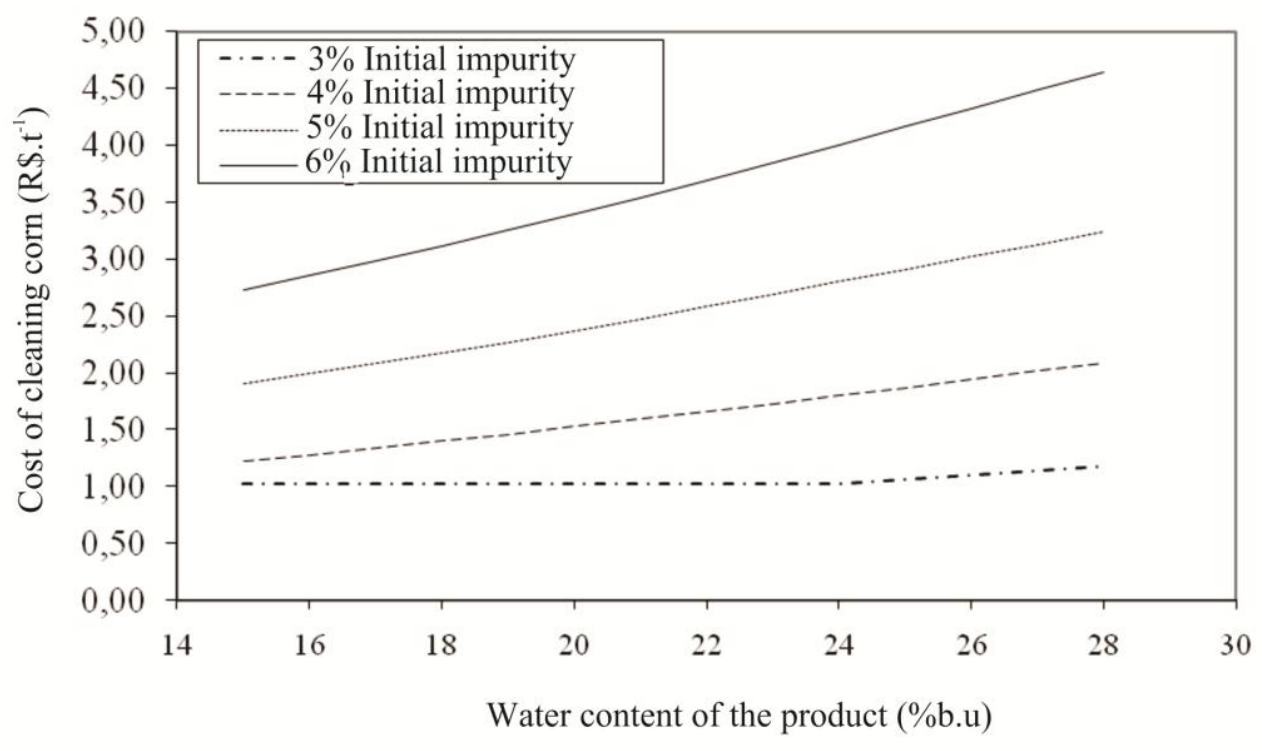

FIGURE 4. Cost of cleaning corn as a function of initial water content of the product for different initial impurity contents.

The cost of cleaning increased as water content of the product increased, showing a linear behavior. However, for an impurity content of 3\%, the cost was constant in the range between $15 \%$ w.b. and $24 \%$ w.b. moisture. This was due to the limited processing capacity of the cleaning system by the grain transportation system. This avoided cost reduction due to the increased processing capability of the cleaning machines for humidity below $24 \%$ wb. Figure 5 shows the cost of storage depending on the occupancy rate of the storage unit.

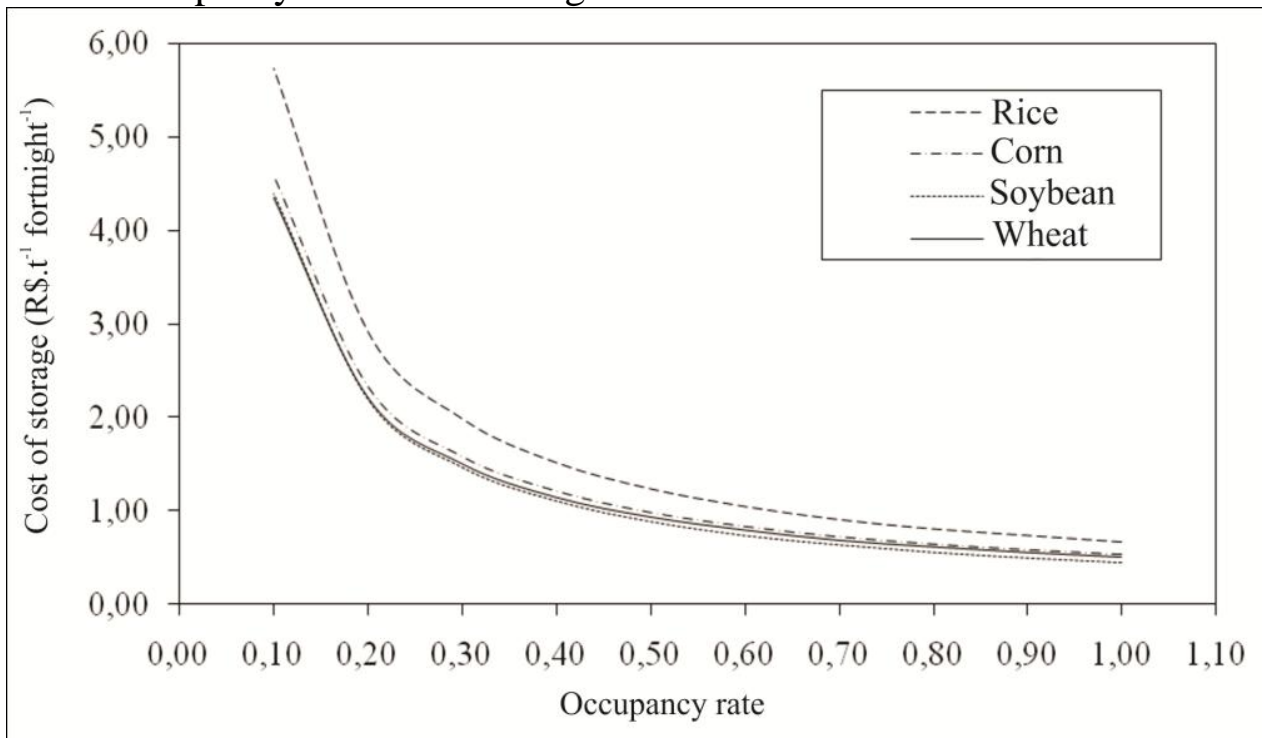

FIGURE 5. Cost of storage as a function of occupancy rate. 
From the analysis of Figure 5, notice that the storage cost grows exponentially with the reduction of the occupancy rate of the storage facility. This is due to a reduced dilution of fixed costs when you have a lower volume of product stored throughout the year, that is, a low occupancy rate. The reduction of storage costs and economic viability by increasing the amount of product stored was also reported by JASPER et al. (2006). Because fixed cost is independent of the amount of product stored, the greater the residence time of the product in the storage facility, the greater the number of fortnights, consequently reducing the fortnight cost per ton of product stored. When a large amount of product is received in the storage unit, this means that there is high turnover. However, if the product received is quickly dispatched, this means that there is a low turnover rate in terms of storage, which is collected per fortnight. This reflects a low occupancy in the storage facility, consequently raising the storage costs.

\section{CONCLUSIONS}

The decision support system proved to be a user-friendly tool. It introduced flexibility to change parameters for the final composition of the costs of reception, cleaning, drying, storage and dispatch.

The increase in the amount of products received in the unit storage reduces exponentially the costs of receiving and dispatch.

The type of product was found as an important parameter in the final costs of storage, drying and cleaning, in which we obtained final costs of $\mathrm{R} \$ 41.52, \mathrm{R} \$ 27.69, \mathrm{R} \$ 25.47$ and $\mathrm{R} \$ 22.92$ per ton of rice, corn, wheat and soybean, respectively.

The lowest rates of drying were obtained using firewood as fuel. Rice showed the highest cost of drying, followed by corn, soybean and wheat.

The average volume of product stored throughout the year, represented by the occupancy rate, changed the storage cost exponentially.

\section{REFERENCES}

ACHOUR, M.; BETZ, F.; DOVGAL, A.; LOPES, N.; OLSON, P.; RICHTER, G.; SEGUY, D.; VRANA, J. PHP Manual, 2007. Disponível em: < http://www.php.net> Acesso em: 25 abr. 2007.

AFONSO JÚNIOR, P. C.; OLIVEIRA FILHO, D.; COSTA, D. R. Viabilidade econômica de produção de lenha de eucalipto para secagem de produtos agrícolas. Engenharia Agrícola, Jaboticabal, v.26, n.1, p.28-35, 2006.

AXMARK, D.; WINDENIUS, M.; LENTZ, A.; DUBOIS, P.; HINZ, S. MySQL 3.23, 4.0, 4.1 reference manual. 2007. Disponível em: < http://www.mysql.com/> Acesso em: 25 abr. 2007.

CONAB. Companhia Nacional de Abastecimento. Central de Informações Agropecuárias.

Disponível em: <http://www.conab.gov.br/conteudos.php?a=1207\&t=2/> Acesso em: 29 abr. 2011.

COSTA, D. R.; LACERDA FILHO, A. F.; SILVA, J. S.; QUEIROZ, D. M.; LIMA, P. N. Análise de custo de sistemas de secagem de milho em secadores mecânicos. Engenharia na Agricultura, Viçosa, MG, v.18, n.1, p.63-76, 2010.

DONZELES, S. M. L.; SILVA, J. S.; CORRÊA, P. C.; SANTOS, R. R.; MAGALHÃES, E. A. Custos comparativos da secagem de café cereja descascado em dois terreiros secadores. Engenharia na Agricultura, Viçosa, MG, v.15, n.2, p.119-129, 2007.

FIELD, F.; KIRCHAIN, R.; ROTH, R. Process cost modeling: strategic engineering and economic evaluation of materials technologies. JOM Journal of the Minerals, Metals and Materials Society, Warrendale, v.59, n.10, p.21-32, 2007. 
FLINN, P. W. Stored Grain Advisor Pro: decision support system for insect management in commercial grain elevators. Journal of Stored Products Research, Oxford, v.43, n.1, p.375-383, 2007.

JASPER, S. P.; BIAGGIONI, M. A. M.; RIBEIRO, J. P. Viabilidade econômica de aquisição de um silo-secador para pequenas áreas de produção. Engenharia Agrícola, Jaboticabal, v.26, n.3, p.795803, 2006.

MERCANTE, E.; SOUZA, E. G.; JOHANN, J. A.; GABRIEL FILHO, A.; URIBE-OPAZO, M. A. PRAPRAG - software para planejamento racional de máquinas agrícolas. Engenharia Agrícola, Jaboticabal, v.30, n.2, p.322-333, 2010.

REINATO, C. H. R.; BORÉM, F. M.; VILELA, E. R.; CARVALHO, F. M.; MEIRELES, E. P. Consumo de energia e custo de secagem de café cereja em propriedades agrícolas do sul de Minas Gerais. Revista Brasileira de Engenharia Agrícola e Ambiental, Campina Grande, local, v.6, n. 1, p.112-116, 2002.

SANTOS, R. R.; LACERDA FILHO, A. F.; SILVA, J. S.; MELO, E. C.; DONZELES, S. M. L. Custos da secagem de café usando-se lenha e carvão vegetal. Engenharia na Agricultura, Viçosa, MG, v.14, n.3, p.179-192, 2006.

SILVA, L. C.; QUEIROZ, D. M.; FLORES, R. A. Estimativa de custos operacionais em unidades armazenadoras de grãos por meio de simulação. Revista Brasileira de Armazenamento, Viçosa, MG, v.31, n.1, p.1-7, 2006.

TILLEY D. R.; LANGEMEIER M. R.; CASADA, M. E.; ARTHUR, F. H. Cost and risk analysis of heat and chemical treatments. Journal of Economic Entomology, Leanham, v.100, n.2, p.604-612, 2007.

VALENTE, D. S. M.; CORRÊA, P. C.; QUEIROZ, D. M.; SILVA, L. C. Impactos da operacionalização de unidades armazenadoras sobre o custo de secagem de milho. Revista Brasileira de Armazenamento, Viçosa, MG, v. 33, p. 60-67, 2008. 